\title{
Remarks About Targeted Killing in the Light of Public International Law
}

Current events on the world political scene lead us to consider how international law should currently realize its goals. It should be taken into account that, apart from striving to maintain international security and peace by creating rules of cooperation between states, international law should also address the use of various forms and methods of force in international relations. The purpose of the latter is to create regulations defining the behavior of states under international law and aimed at ensuring international order in the world. This is important due to the fact that while in the sphere of domestic solutions the monopoly of state institutions on the use of force was developed, international law refers to this issue as an effect of the fact that it has no special instruments that would not only regulate the use of force, but would also minimize the effects of its use.

Currently, we use the term "use of force" when referring to a situation in which violence is used in a manner close to the technical characteristics of the state of war, as well as to military operations that do not encounter armed resistance.

Without going into more detailed considerations regarding the essence of force, it should be defined as a directed power, in the sense of being turned or used against someone or something. International law regulations concerning its application, not having the character of norms of the value of iuris cogentis, accept that force may be resorted 
to. However, while its application by UN states and armed forces is, in principle, obvious, controversy arises from non-state participants of the international community resorting to it, through the use of cyber resources and hybrid attacks, against which most countries are basically unprepared.

Can these non-classical ways be compared with the use of armed force? Considering the effects, sometimes comparable to the effect of the classic use of military force, an affirmative answer should not be excluded. This is all the more important when it is taken into account that a victim of assault is defined under international law, but the perpetrator is not clearly defined, which means that the latter may not always be a state.

Therefore, international law must adapt to the existing reality, while striving to recognize the legitimacy of the use of force, often without anyone's consent, despite the possibility of questioning the legality of such actions. Is this a solution to the problem?

Certainly not, because, for example, events in Ukraine, in particular in Crimea, in Syria, or during the fights against the so-called Islamic State of Iraq and Syria (ISIS), reveal that the thesis of the twilight of power as an instrument of politics cannot be defended. On the one hand, to ensure its own security and to defend the international order based on values, not just interests, the role of international law should be emphasized, and, on the other - if it is to be effective, situations justifying recourse to force should be defined.

Therefore, clarifying the situation related to the use of force in the context of new threats is a significant challenge to international law, and one which it must face, otherwise the existing political and economic system will be shaken, and as a consequence the values constituting the basis of international order will be abandoned.

The issue is also important due to the fact that the territory of one state is made available in different forms for operations conducted against another state, which is often associated with undertaking preventive armed operations against another state or non-state actors (e.g. against 
the so-called Islamic state). It may also be associated with the so-called deliberate killing of specific persons responsible for planning or performing terrorist acts in another country, but not against it ${ }^{1}$, which in the international legal sphere is referred to as targeted killing. ${ }^{2}$ This raises numerous doubts, recently particularly emphasized in connection with the order of the President of the United States, Donald Trump, to conduct on 3 January 2020 with the help of an unmanned aerial vehicle, i.e. a drone, an air raid on an airport in Baghdad (Iraq), which was aimed at killing the Iranian general Kasem Suleimani - commander of the Iranian branch of Ghods. ${ }^{3}$

This event raised the basic question: was the action of the American state authorities in accordance with applicable international law, specifically with the right to self-defense functioning in the sphere of international law, guaranteed by both common law and art. 51 of the Charter of the United Nations?

In reply, it should be stated that, although the contemporary framework for the admissibility of recourse to self-defense is set by the UN Charter, which states in art. 51 that "Nothing in the present Charter shall impair the inherent right of individual [...] self-defence [...], until the Security Council has taken measures necessary to maintain international peace and security"4, this law as an inherent right is recognized by all legal systems in accordance with the principle that vim vi repellere omnia iura permittunt (all laws allow force to be resisted with force).

Nevertheless, the question arises of whether this means that in international law there exists a law that stands above the provisions of Article 51 of the UN Charter, which refer only to the situation involving the occurrence of an armed attack? In answering this question, reference should be made to the 1986 Nicaragua ruling, in which the International

1 J. Kranz, Zakaz użycia siły in: Wielka Encyklopedia Prawa, Prawo międzynarodowe publiczne, ed. J. Symonides, D. Pyć, Warszawa 2014, vol. IV, p. 578.

2 Ibidem, p. 578.

3 J. Bielecki, Trump wyczuł Irańczyków, “Rzeczpospolita” 13 January 2020.

4 Journal of Laws of 1947, no. 23, item 90. 
Court of Justice stated, inter alia, that the right to self-defense, which is by its very nature associated with the use of armed force, is a natural right vested in every state both on the basis of common law and the provisions of the UN Charter. ${ }^{5}$ However, in order for a state to refer to this right as a part of self-defense, it must be able to prove that it has been the victim of an armed assault. Therefore, the burden of proof falls on such a state, which can sometimes be difficult to establish, especially when there are various types of non-state formations behind the armed attack. ${ }^{6}$ And this is all the more important as the definition of armed assault is lacking, although when trying to define it, it should be stated that it is characterized by a larger or smaller scale of short-term or repeated armed attacks. Nevertheless, the legality of recourse to selfdefense is subject to control by the UN Security Council, which means that it appertains formally until the Security Council takes the measures and methods necessary to restore peace and security.

This statement is subject to dispute, because with regard to self-defense all countries are free to act, including with the use of armed force, if the situation so requires, because, as emphasized in a separate opinion expressed by one of the ICJ judges in the judgment of this Tribunal in the abovementioned Nicaragua case - it is dangerous and unnecessary to strictly define the conditions of lawful self-defense, leaving a large area where armed response to violence is in fact prohibited and where there has also been no use of force by the United Nations to fill the gap. ${ }^{7}$ In many situations, it is difficult to determine the moment when an armed assault began, and thus establish that the requirements of Article 51 of the UN Charter and thus the conditions for the use of force in self-defense were met. For example, do attacks by various armed associations against for-

5 “International Court of Justice Reports” 1986, pp. 543-544; 76 “International Court of Justice Reports” 1986, p. 349 and 428.

6 J. Kranz, Zakaz użycia siły, p. 577.

7 “International Court of Justice Reports” 1986. See MTS advisory opinion: Legalność użycia broni nuklearnej ICJ, Reports, 1996, p. 226 and 246. Y. Dinstein, Conduct of Hostilities under the Law of International Armed Conflict, Cambridge 2004, p. 220 and next. 
eign diplomatic or consular representations constitute an armed assault justifying self-defense by the state whose representation suffered damage?

The United States takes the view that the response to the use of armed force in such a situation is in accordance with Article 51 of the UN Charter, in which case the right to self-defense is exercised. ${ }^{8} \mathrm{~A}$ similar approach can also be seen in Security Council Resolution 1701 (2006), in which it was recognized that particularly hostile actions of non-state actors could be treated as synonymous with assault, thus justifying the exercise of the victim's right to self-defense. ${ }^{9}$

In relation to the killing of the Iranian general, a number of questions arise, such as whether the US recourse to self-defense was justified by the fact that the country considered itself to have suffered harm, or whether there were there other arguments justifying US actions.

When analyzing US actions, it should be taken into account that the action against the Iranian general was performed without the consultation and consent of the Iraqi authorities, otherwise the problem of Iraq's joint responsibility would have arisen, as the Iraqi authorities had received the official representative of the foreign army on their territory, who had come to Iraq on an official visit aimed at representing Iran in talks with the Iraqi government.

In answer to these questions, it should be noted that the basis / source of the incident at Baghdad airport are the conflicting political and military interests of Iran and the United States. The former country is seeking to become a Middle Eastern hegemon and holds that actions related to the United States and its presence in the Middle East should be countered and combated. On the other hand, the US assumes that the actions taken by the Iranian authorities in the political and military sphere significantly contribute to the violation of American interests in this part of the world, especially when it comes to the freedom of navigation in

8 M.N. Shaw, Prawo międzynarodowe publiczne, Warszawa 2011, p. 696; see also: Contemporary Practice of the United States, "American Journal of International Law" 1999, vol. 93 , p. 161.

9 M.N. Shaw, Prawo międzynarodowe..., p. 698. 
the Persian Gulf, whose waters transport more than a quarter of the oil extracted. Thus, in response to the damage caused mainly by the Iranian troops of Ghods, recognized as a terrorist formation because of their means and methods of action, it was decided that in this situation preemptive self-defense actions should be taken in Iraqi territory, where according to the intelligence information, General K. Sulejmani would be staying, dictated by the need to thwart the Iranian attack or a series of such attacks against the US and its property. ${ }^{10}$

The question of the legitimacy of this type of action is emerging here.

In response, it should be stated that it does not contradict the essence of art. 51 of the UN Charter ${ }^{11}$, while the assessment of demonstrating the lack of other options and taking into account the criteria of immediacy, necessity and proportionality raises a question.

Referring, inter alia, to the already cited ruling of the International Court of Justice of 1986 in the Nicaragua case, it should be noted that the ICJ clearly acknowledges that changing the premises and objectives, as well as the methods and means, of fighting with the use of the armed force, leads to the emergence of new concepts. These, in the event of extraordinary circumstances, are intended to justify the use of unilateral military measures without the consent of the UN Security Council. This represents, to a certain extent, a departure from the essence of the Declaration of principles of international law concerning friendly relations and the cooperation of states in accordance with the United Nations Charter of 24 October 1970, in which it is stated, in the part relating to the prohibition of the use of force, that each country has the

10 Quotation for: <https://www.defense.gov/Newsroom/Releases/Release/Article/2049534/ Statement-by-the-department-of-defense/>.

11 See the report of a group of experts appointed by the UN Secretary General: A More Secure World: Our Shared Responsibility, 2004, point 188; Report of the UN Secretary General: In Larger Freedom: Towards Security, Development and Human Right for All: 2005, point 124; H. Waldock, General Course on Public International Law, "166 Hague Academy of International Law. Recueil des Cours” 1980, pp. 231-237. 
obligation to refrain from organizing in another country activities aimed at committing acts involving the use of or threat to use force. ${ }^{12}$

This is because in recent decades the conditions for referring to the use of force and actors on the political scene have changed. This requires not only adaptation, but also interpretation of international legal norms in the context of new threats which necessitate, nolens volens, sometimes using unilateral means of removing an opponent without the consent of the UN Security Council, in the form of 'targeted killing', i.e. physical elimination, at the request of the government of the state and with the help of its organs, of specific persons responsible for the preparation of terrorist acts ${ }^{13}$ - in other words acts of violence irrespective of the motives or intentions of the perpetrators, committed to perform criminal acts with the intention of causing a sense of threat to the safety of life, freedom or social stability, violation of territorial integrity, in order to force the government to act or desist from acting.

Intentional physical elimination is carried out on the territory of another state without being directed precisely against it, usually in a situation where the other state is unable to ensure security and does not control the person preparing terrorist acts, or who participates in their implementation. In terms of the activities of General K. Sulejmani, these were directed against the United States, which in this situation justified his possibly quick and even necessary physical elimination, as direct capture of K. Sulejmani was unrealistic. It was assumed that such a precise attack directed against one person falls within the limits of both basic necessity and proportionality in relation to potential other victims, whose death could not have been avoided, including the Iraqi commander of the People's Mobilization Force - the police force fighting on the Iraqi side with the so-called Islamic State (ISIS).

12 K. Kocot, K. Wolfke, Selection of documents for learning international law, WrocławWarszawa 1976, pp. 524-533.

13 Cit. per: W. Czapliński, A. Wyrozumska, Prawo międzynarodowe publiczne. Zagadnienia systemowe, Warszawa 2004, pp. 696-698. 
Another example of intentional elimination was the killing of the Saudi Osama bin Laden, the leader of the terrorist organization Al-Qaida (Base) and the main organizer of the terrorist attack on the New York World Trade Center in September 2001, by a special American unit in May 2011 in Pakistan. ${ }^{14}$

These remarks lead to conclusions of a more general nature, namely that modern states, despite the existing legal regulations, are primarily guided by the reason of state, which has primacy over human rights, as well as international legal regulations. In this regard, one can conclude that American actions in the Middle East are part of a broader deterrence strategy not only for Iran, but also for other unnamed enemies of America.

However, looking through the prism of this event, it is a more political than a legal reflection to suggest that the President of the United States, who was at risk of impeachment, sought to show, during an important trial with Iran, that he was determined in to ensure the security of the country and its population.

Finally, there is also the issue of legal assessment of the event in question, which should take the following into account: in order to be an effective guarantor of the existing international order, international law must take into account that, along with changing beliefs about its effectiveness, values also often change with interests. These are manifested in: strength that determines not only the power of the country, but also the goals and directions of the state's activities in a way that often deviates from the established principles of the international order and a policy emphasizing security. This is a value that impacts international legal ventures and something that usually has far-reaching repercussions, pushing the legal boundaries of what is acceptable and imaginable, and therefore, in order for international law to be- to emphasize this once again-effective, it cannot be passive, let alone indifferent.

Hence, being in favor of acknowledging the effects of the case in question, it should be emphasized that, despite obvious controversies

14 J. Kranz, Zakaz użycia siły, p. 578. 
regarding the use of force as part of pre-emptive defense, the result of which is, inter alia, the deliberate elimination of a specific person / persons, this action should be considered legal, together with the requirement / criterion of necessity and proportionality, which in relation to the second requirement is not always observed or complied with.

\section{References}

Bielecki J., Trump wyczuł Irańczyków, “Rzeczpospolita”, 13 January 2020.

Conterporary practice of the United States, “American Journal of International Law” 1999, vol. 93.

Czapliński W., Wyrozumska A., Prawo międzynarodowe publiczne. Zagadnienia systemowe, Warszawa 2004.

Dinstein Y., Conduct of Hostilities under the Law of International Armed Conflict, Cambridge 2004.

Kocot K., Wolfke K., Selection of documents for learning international law, Wrocław-Warszawa 1976.

Kranz J., Zakaz użycia siły, in: Wielka Encyklopedia Prawa, Prawo międzynarodowe publiczne, Warszawa 2014, vol. IV.

Shaw M.N., Prawo międzynarodowe publiczne, Warszawa 2011.

Waldock H., General Course on Public International Law, “166 Hague Academy of International Law. Recueil des Cours” 1980.

Human Right for All, New York 2005, point 124.

International Law Reports 76, 1986.

Journal of Laws of 1947, no. 23, item 90.

Report of a group of experts appointed by the UN Secretary General: A More Secure World: Our Shared Responsibility, New York 2004, point 188.

Report of the UN Secretary General: In Larger Freedom: Towards Security, Development and Human Rights for All. 
ICJ Reports of Judgments, Advisory Opinions of 8 July 1996 on Legality of the Threat or Use of Nuclear Weapons.

$<$ https://www.defense.gov/Newsroom/Releases/Release/Article/2049534/ Statement-by-the-department-of-defense/>.

\section{SUMMARY}

\section{Remarks About Targeted Killing in the Light of Public International Law}

The premises concerning the use of force are currently changing, as are the goals and methods, which entails that appropriate adaptation and interpretation of international legal norms is required in the context of new threats and methods of combating them. This constitutes a significant problem, especially in the event of extraordinary circumstances that are to justify the use of unilateral measures without the consent of the UN Security Council.

This encompasses, inter alia, the issue of targeted killing, i.e. eliminating in the territory of another state, while not operating against such a state, on the order of a specific government, a specific person responsible for the illegal use of force, if other methods of apprehending the perpetrator are unrealistic. This makes such a method, in a given circumstance, a legal form of combat, as long as the criterion of necessity and proportionality is taken into account.

Keywords: international law, targeted killing, pre-emptive self-defense, necessity, proportionality, reason of state.

Piotr Łaski, University of Szczecin, Narutowicza 17a, Szczecin, Republic of Poland, e-mail: piotr.laski@usz.edu.pl.

DOI 10.14746/ppuam.2020.11.03 